\title{
Concentrated Extract of Green Tea Polyphenols Enhances the Toxicity of the Elderberry Lectin Nigrin b to Mice
}

\author{
Pilar Jiménez $^{1}$, Patricia Cabrero ${ }^{1}$, Jesús Tejero ${ }^{1}$, Manuel J. Gayoso ${ }^{2}$, Manuel Garrosa ${ }^{2}$, \\ Damián Cordoba-Diaz ${ }^{3}$, Manuel Cordoba-Diaz ${ }^{3}$, Tomás Girbés ${ }^{{ }^{*}}$

\begin{abstract}
${ }^{1}$ Nutrición y Bromatología, Facultad de Medicina and CINAD (Centro de Investigación en Nutrición, Alimentación y Dietética Edificio LUCIA-Parque Científico), Universidad de Valladolid, Valladolid, Spain; ${ }^{2}$ Biología Celular, Histología y Farmacología, Facultad de Medicina and INCYL (Instituto de Neurociencias de Castilla y León), Universidad de Valladolid, Valladolid, Spain; ${ }^{3}$ Farmacia y Tecnología Farmacéutica, Facultad de Farmacia and IUFI (Instituto Universitario de Farmacia Industrial), Universidad Complutense de Madrid, Madrid, Spain.
\end{abstract} \\ Email: "girbes@bio.uva.es
}

Received November $11^{\text {th }}, 2013$; revised December $12^{\text {th }}, 2013$; accepted December $19^{\text {th }}, 2013$

Copyright @ 2014 Pilar Jiménez et al. This is an open access article distributed under the Creative Commons Attribution License, which permits unrestricted use, distribution, and reproduction in any medium, provided the original work is properly cited. In accordance of the Creative Commons Attribution License all Copyrights (C) 2014 are reserved for SCIRP and the owner of the intellectual property Pilar Jiménez et al. All Copyright (C) 2014 are guarded by law and by SCIRP as a guardian.

\section{ABSTRACT}

The effect of the administration of large amounts of green tea polyphenols is a matter of controversy. We explored whether a polyphenol mixture from a concentrated green tea extract (Polyphenon 60) could alter the effects on mice of the type 2 (two chains) ribosome-inactivating protein nigrin b isolated from Sambucus nigra L. Nigrin b triggers specific reversible toxic effects on the mouse intestines featured by apoptosis of mice Lieberkühn crypt cells upon parenteral administration of sub-lethal amounts. Independent administration to mice of $30 \mathrm{mg} / \mathrm{kg}$ body weight of Polyphenon 60 by oral gavage or $10 \mathrm{mg} / \mathrm{kg}$ body weight of nigrin b administered via the intraperitoneal route (i.p.) did not affect survival. In contrast, the simultaneous treatment greatly enhanced nigrin b toxicity leading to the death of some animals. The histological analysis revealed that the most serious injury was inflicted on the small intestine crypts, which disappeared, and on the liver, which evidenced hepatotoxicity showing haemorrhagic areas. These findings raise concerns about the abuse of high concentrations of green tea polyphenols especially when the intestinal mucosa is damaged, for instance by toxins or therapeutic drugs.

\section{KEYWORDS}

Green Tea Polyphenols; Nigrin b Model; Ribosome-Inactivating Protein; Lectin; Small Intestine; Liver; Apoptosis

\section{Introduction}

The benefits of green tea polyphenols (GTP) consumption have been scientifically established. GTP are a source of valuable phytochemical compounds whose consumption may improve health and constitute a protection factor against some pathologies, especially cardiovascular disorders and cancer [1-2]. Green tea polyphenol catechins seem to be highly active molecules acting as prooxidant [3], antioxidant [2], anti-inflammatory [4] and anticancer [5] agents. Epigallocatechin gallate is the most

*Corresponding author. widely studied compound [1]. Among the standardized preparations enriched in polyphenols is Polyphenon 60, which has been used in studies on inflammation-related colon carcinogenesis in mice [4] and in studies of catechin pharmacokinetics in healthy human beings [5]. The combination of epigallocatechin gallate and sulindac significantly enhanced apoptosis in rat colon, reducing the aberrant crypt foci [6]. Despite these positive effects, administration of concentrated green tea extracts has been shown to trigger certain adverse effects that rise concerns from a food safety point of view [7-9].

Plant ribosome-inactivating proteins (RIPs) are wide- 
spread throughout the plant kingdom [10,11] and are also present in fungi [12]. It is believed that they belong to the plant defence system against insects, viruses and fungi [13-15]. Interest in RIPs derives from their use in anticancer immunotoxins and conjugate preparations [1618]. Among these proteins are nigrin from elderberry (Sambucus nigra L.) [19] and ebulin from dwarf elder (Sambucus ebulus L.) [20]. Administering large amounts of nigrin b caused serious intestinal derangement that at high concentrations might lead to death [21]. In a previous light microscopy histological analysis, we reported that mice treated with sub-lethal doses of nigrin b revealed severe alteration of small intestine stem cells and transit-amplifying compartment (TAC) present in the crypts, displaying apoptotic-like morphology, including cell shrinkage and increased cytoplasmic eosinophilia. However, Paneth cells, which are located underneath TAC in the crypts, seemed to be spared [19,22]. A recent report from our laboratory used sub-lethal nigrin $\mathrm{b}$ administration to mice as a model for the study of vitamin B6 uptake [23]. The objective of the present research was to investigate whether administering GTP to nigrin binjured mice would affect the damaging action of sublethal nigrin $b$ on the mouse intestinal mucosa, and the survival of the animals.

\section{Materials and Methods}

\subsection{Chemicals}

Polyphenon 60 preparation obtained from Sigma-Aldrich Química S.A. (Tres Cantos, Spain) was used as green tea polyphenols mixture. Polyphenon 60 contains the following composition (\%): (-) epigallocatechin (EGC), 21.0; (-) epicatechin (EC), 7.3; (-) epigallocatechin gallate (EGCG), 29.2 and (-) epicatechin gallate (ECG), 7.9 [24]. Polyphenon 60 was prepared freshly in water. All other biochemical reagents were of the highest grade commercially available. Isofluorane was obtained from Laboratorios Dr. Esteve S.A. (Barcelona, Spain). Histological reagents were obtained as reported earlier [22].

\subsection{Nigrin b Preparation}

Highly purified nigrin b was prepared from elderberry bark by the affinity chromatography procedure to ensure the maximal activity as described elsewhere [25]. Purity was assessed by sodium dodecyl sulphate polyacrylamide gel electrophoresis. Nigrin b was administered as $0.1 \mathrm{~mL}$ of a solution containing the indicated amount of nigrin $\mathrm{b}$ in $0.1 \mathrm{M}$ phosphate-buffered saline, $\mathrm{pH}$ 7.4.

\subsection{Animals and Treatment}

28 Swiss female mice (6 weeks old; 28 - 30 g body weight) obtained from the university facilities were housed individually in plastic cages and fed (V1535-000 Ssniff Specialdiäten GmbH) ad libitum with free access to water under a $12 \mathrm{~h}$ light-dark cycle. One group $(\mathrm{n}=7)$ was administered nigrin $b$ by an intraperitoneal injection of $0.1 \mathrm{~mL}$ of a solution containing the indicated amount of nigrin $\mathrm{b}$ in $0.1 \mathrm{M}$ phosphate-buffered saline, $\mathrm{pH}$ 7.4. A second group $(n=7)$ was treated orally with either 16 or $30 \mathrm{mg} / \mathrm{kg}$ body weight of Polyphenon 60 administered as solution in water with a blunted end needle attached to a $1 \mathrm{~mL}$ syringe. A third experimental group $(\mathrm{n}=7)$ was treated simultaneously with either 16 or $30 \mathrm{mg} / \mathrm{kg}$ Polyphenon 60 plus $10 \mathrm{mg} / \mathrm{kg}$ body weigh i.p. nigrin b. Finally, a fourth group of animals $(n=7)$ was untreated and used as control. Handling of the animals followed the European Communities Council guidelines (2010/63/ EU) for laboratory animal care and experimentation under the guidelines of the animal facilities of the University of Valladolid. Euthanasia was conducted previous anaesthesia with isofluorane.

\subsection{Histological Analysis}

For histological analysis, animals were anaesthetized with isoflourane and perfused transcardially with $4 \%$ paraformaldehyde in $0.1 \mathrm{M}$ phosphate-buffered saline (PBS) $\mathrm{pH} 7.4$, processed for paraffin embedding and stained with haematoxylin-eosin as described elsewhere [22].

\section{Results and Discussion}

Oral administration of 16 or $30 \mathrm{mg} / \mathrm{kg}$ body weight of Polyphenon 60 to Swiss female mice had no visible effects (Figure 1). Likewise, intraperitoneal administration of $10 \mathrm{mg} / \mathrm{kg}$ nigrin did not affect animal survival or trigger apparent and visible damage (Figure 1). In contrast, oral administration of either 30 or $16 \mathrm{mg} / \mathrm{kg}$ Polyphenon 60 to mice treated simultaneously with $10 \mathrm{mg} / \mathrm{kg}$ body weight i.p. nigrin $b$ reduced mice survival of animals sensitive to the treatment. Animals killed by the combined treatment showed dark areas in some segments of the small intestine probably by haemorrhage. It was noteworthy that the higher the Polyphenon 60 concentration in the combined treatment was, the shorter resulted to be the period to trigger lethal effects. At the highest concentration of Polyphenon 60 the combined treatment started to show lethal effects after 3 days, while at the lowest dose of Polyphenon 60, some animals started to die after 8 days. As we wanted to study only the early toxicity, the experiments were discontinued after 14 days once obtained a clear idea of the effect.

As shown in Figure 2, histological analysis revealed that mice treated with oral doses of $30 \mathrm{mg} / \mathrm{kg}$ Polyphenon 60 evidenced no intestinal derangement and, as in the control animals, showed well-formed Lieberkühn 


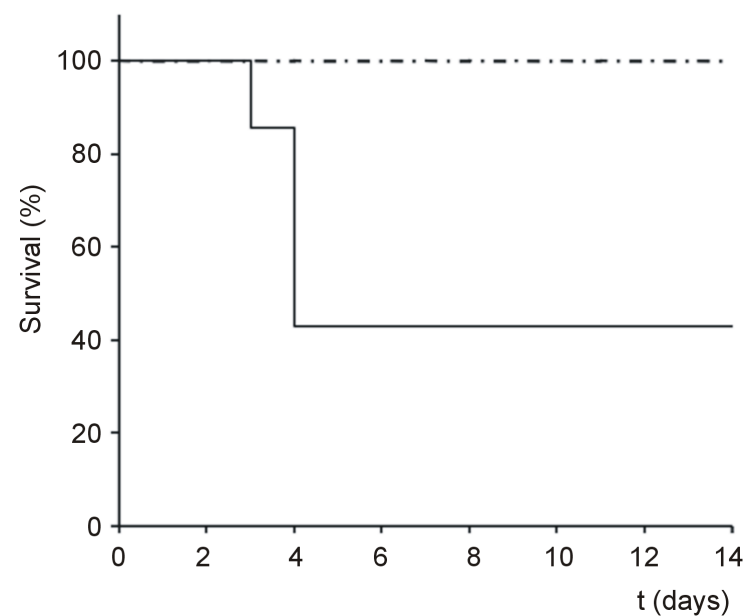

(A)

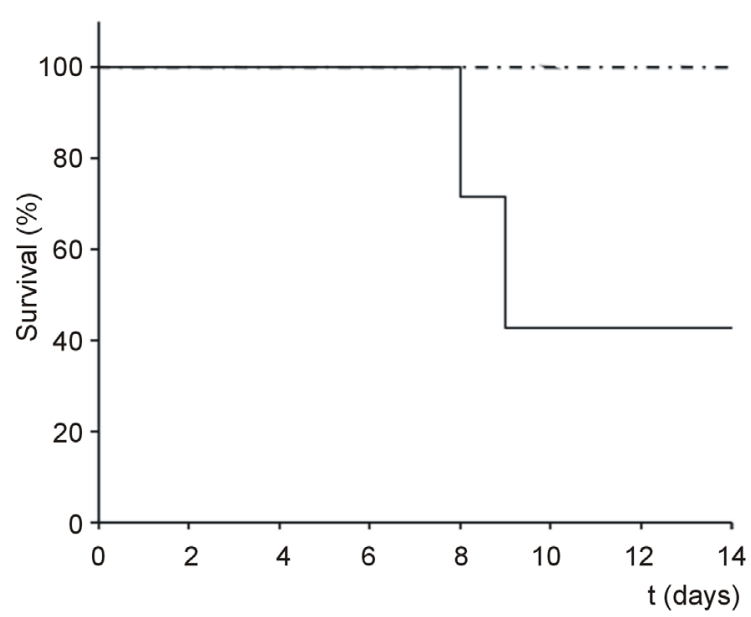

(B)

Figure 1. Kaplan Meier plots of the toxicity of nigrin $b$ and Polyphenon 60 in mice. Groups of animals $(n=7)$ were treated simultaneously with 30 (A) or 16 (B) $\mathrm{mg} / \mathrm{kg}$ body weight Polyphenon 60 (oral) and $10 \mathrm{mg} / \mathrm{kg}$ body weight nigrin $b$ (i.p.) and the survival was plotted versus days after treatment (dot-dashed line: Polyphenon 60 alone and nigrin $b$ alone; continuous line: Polyphenon 60 plus nigrin b).

crypts and villi (Figures 2(A) and (C)). In contrast, after $24 \mathrm{~h}$ of intraperitoneal administration of $10 \mathrm{mg} / \mathrm{kg}$ nigrin $\mathrm{b}$, significant but reversible derangement of the small intestine was apparent, which led to the almost complete disappearance of the Lieberkühn crypts (Figure 2(D)). In this group, the epithelium of the crypts displayed a large number of dying cells showing apoptotic-like morphology including condensation of the chromatin with aggregation in peripheral masses, and ultimate formation of apoptotic bodies (Figure 2(D)); nevertheless the general structure of the intestinal villi was normal and their covering epithelium evidenced only minor shrinkage in the basal cytoplasm (Figure 2(D)). Simultaneous oral administration of $30 \mathrm{mg} / \mathrm{kg}$ Polyphenon 60 and intraperitoneal $10 \mathrm{mg} / \mathrm{kg}$ nigrin $b$ revealed that the small intestines
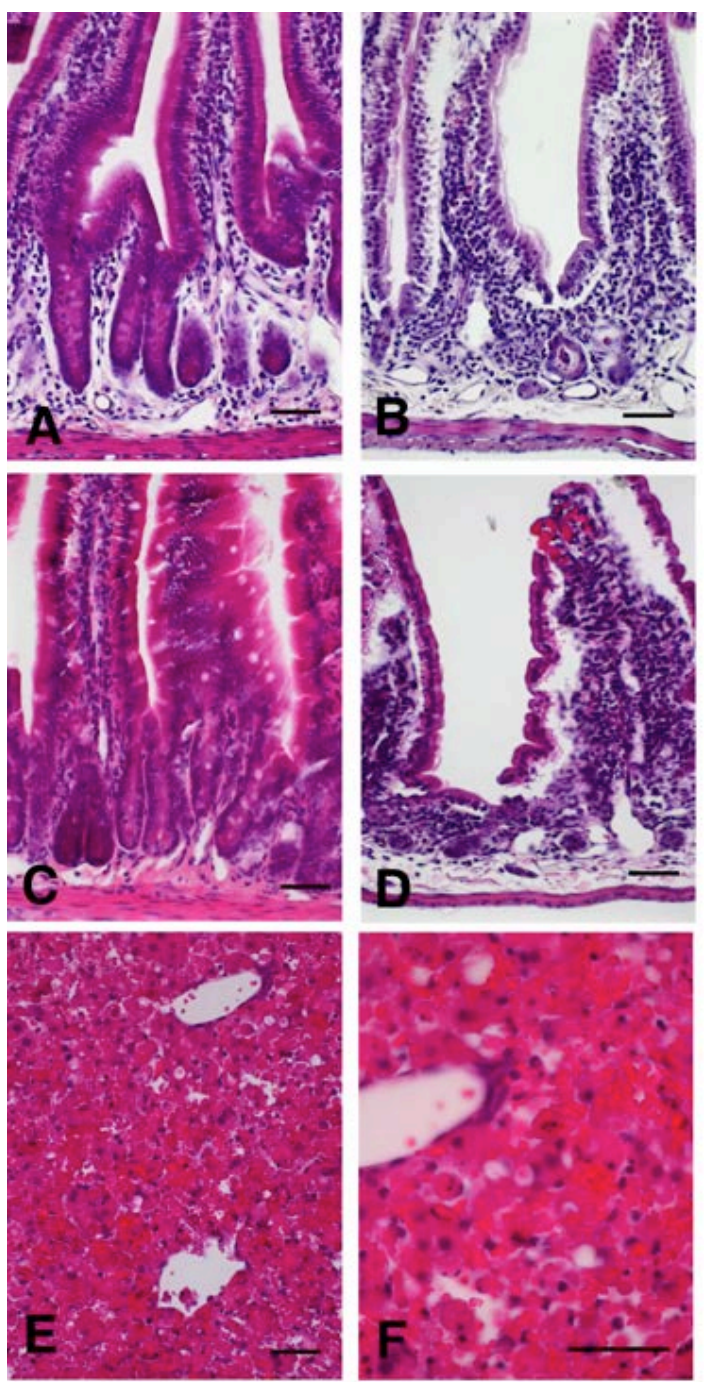

Figure 2. Histological sections stained with haematoxylin and eosin of small intestines (A-D) and liver (E-F) in mice treated with Polyphenon 60 and nigrin $b$ as explained. (A) control; (B) i.p. $10 \mathrm{mg} / \mathrm{kg}$ body weight nigrin plus oral 30 $\mathrm{mg} / \mathrm{kg}$ body weight Polyphenon 60; (C) oral $30 \mathrm{mg} / \mathrm{kg}$ body weight Polyphenon 60; (D) i.p. $10 \mathrm{mg} / \mathrm{kg}$ body weight nigrin; (E) and (F) Haemorrhage in the liver of mice treated with i.p. $10 \mathrm{mg} / \mathrm{kg}$ body weight nigrin $b$ and oral $30 \mathrm{mg} / \mathrm{kg}$ body weight Polyphenon 60 simultaneously. Scale bar $=25$ $\mu \mathrm{m}$.

were severely affected (Figure 2(B)), even more so than with nigrin b alone. Simultaneous administration of both agents caused almost complete destruction of the small intestine crypts. The structure of the large intestine was generally well preserved by that time (data not shown).

Numerous reports highlight the benefits of green tea consumption [26-28]. However, several detrimental effects associated to the ingestion of large amounts of green tea or preparations of green tea enriched with polyphenols have been reported [7,9]. Of particular concern is the hepatotoxicity presumably resulting from the in- 
gestion of concentrated green tea extracts [8,29-31]. Concerning the mechanism of hepatotoxicity, it is not completely understood, but some components like catechins and their gallic acid esters, particularly epigallocatechin3-gallate which, under certain conditions such as fasting, can induce reactive oxygen species formation, and affect mitochondrial membrane potential [32], are likely to constitute an important part of such effect. A recent published review suggest than patterns of liver injury were hepatocellular in most cases, but cholestasis and a mixed pattern were also observed. Liver histology examination revealed inflammatory reactions, cholestasis, occasional steatosis and necrosis [33]. We therefore investigated the effects of simultaneously administering nigrin b (i.p.) and Polyphenon 60 (oral) on liver, lungs and kidney. While lungs and kidney were slightly congested (data not shown), the liver showed signs of haemorrhage (Figures $2(\mathrm{E})$ and $(\mathrm{F})$ ). Our results suggest that the apoptotic action of nigrin $b$ on the small intestine crypts may be enhanced by the proapoptotic effects of polyphenols resulting in an increased rate of cell destruction. In fact, a synergistic apoptotic action of both sulindac and (-)-epigallocatechin-3-gallate has been reported [6]. The effect could be exerted through the increase of the plasma membrane receptor for lectin, which might increase tissue sensitivity to nigrin b, or alternatively be caused by polyphenol-dependent amplification of the apoptotic signals triggered by nigrin b. The present findings support the emerging belief that consuming large amounts of polyphenols may promote adverse effects when the intestines are injured. Further work will address the potential apoptotic mechanism of the observed toxic synergy between both Polyphenon 60 and nigrin b.

\section{Conclusion}

This study revealed that neither oral administration of large doses of GTP nor i.p. administration of sub-lethal nigrin b separately showed an effect on survival of mice. However, the oral administration of GTP to simultaneously nigrin b-treated animals was found to enhance nigrin b-dependent toxicity in mice, suggesting that GTP and/or GTP-derived active metabolites potentiate the derangement promoted by nigrin $b$ on the small intestine crypt cells. Our results would prove useful for cancer therapy research that uses polyphenols as driving therapeutic drugs or as adjuvant supporting conventional therapy and also raise concerns on the use and abuse of concentrated green tea extracts as a food antioxidant supplement, in particular when a simultaneous toxin-driven tissue derangement occurs.

\section{Acknowledgements}

This study was supported by grants from the Regional
Government of Castilla y León [Junta de Castilla y León] (GR106-Regional Education Ministry and Regional Health Ministry) and UVa-GIR, the Complutense University UCM/CAM research group 950247 as well as MAT2010-21621 C02-01 from the Ministry of Innovation and Science (Spain). We also wish to thank J.E. Basterrechea, U.L. Santiago and T. Rodríguez for technical assistance, and Philip Jaggs for manuscript correction.

\section{REFERENCES}

[1] J. Kanwar, M. Taskeen, I. Mohammad, C. Huo, T. H. Chan and Q. P. Dou, "Recent Advances on Tea Polyphenols," A Frontiers in Bioscience (Elite Edition), Vol. 4, 2012, pp. 111-131. http://dx.doi.org/10.2741/363

[2] C. S. Yang, X. Wang, G. Lu and S. C. Picinich, "Cancer Prevention by Tea: Animal Studies, Molecular Mechanisms and Human Relevance," Nature Reviews Cancer, Vol. 9, No. 6, 2009, pp. 429-439.

http://dx.doi.org/10.1038/nrc2641

[3] Z. Hou, S. Sang, H. You, M. J. Lee, J. Hong, K. V. Chin and C. S. Yang, "Mechanism of Action of (-)-Epigallocatechin-3-Gallate: Auto-Oxidation Dependent Inactivation of Epidermal Growth Factor Receptor and Direct Effects on Growth Inhibition in Human Oesophageal Cancer KYSE 150 Cells,” Cancer Research, Vol. 65, No. 17, 2005, pp. 8049-8056.

[4] Y. Shirakami, M. Shimizu, H. Tsurumi, Y. Hara, T. Tanaka and H. Moriwaki, "EGCG and Polyphenon E Attenuate Inflammation-related Mouse Colon Carcinogenesis Induced by AOM plus DDS," Molecular Medicine Reports, Vol. 1, No. 3, 2008, pp. 355-361.

[5] M. Shimizu, S. Adachi, M. Masuda, O. Kozawa and H. Moriwaki, "Cancer Chemoprevention with Green Tea Catechins by Targeting Receptor Tyrosine Kinases,” Molecular Nutrition and Food Research, Vol. 55, No. 6, 2011, pp. 832-843. http://dx.doi.org/10.1002/mnfr.201000622

[6] T. Ohishi, Y. Kishimoto, N. Miura, G. Shiota, T. Kohri, Y. Hara, J. Hasegawa and M. Isemura, "Synergistic Effects of (-)-Epigallocatechin Gallate with Sulindac Against Colon Carcinogenesis of Rats Treated with Azoxymethane,” Cancer Letters, Vol. 177, No. 1, 2002, pp. 49-56. http://dx.doi.org/10.1016/S0304-3835(01)00767-4

[7] A. H. Schönthal, "Adverse Effects of Concentrated Green Tea Extracts,” Molecular Nutrition and Food Research, Vol. 55, No. 6, 2011, pp. 874-885. http://dx.doi.org/10.1002/mnfr.201000644

[8] J. D. Lambert, M. J. Kennett, S. Sang, K. R. Reuhl, J. Ju and C. S. Yang, "Hepatotoxicity of High Oral Dose (-)Epigallocatechin-3-Gallate in Mice,” Food and Chemical Toxicology, Vol. 48, No. 1, 2010, pp. 409-416. http://dx.doi.org/10.1016/j.fct.2009.10.030

[9] A. Jain, C. Manghani, S. Kohli, D. Nigam and V. Rani, “Tea and Human Health: The Dark Shadows," Toxicology Letters, Vol. 221, No 1, 2013, pp. 82-87. http://dx.doi.org/10.1016/j.toxlet.2013.04.010 
[10] F. Stirpe, “Ribosome-Inactivating Proteins,” Toxicon, Vol. 44, No. 4, 2004, pp. 371-383. http://dx.doi.org/10.1016/j.toxicon.2004.05.004

[11] T. Girbés, J. M. Ferreras, F. J. Arias and F. Stirpe, “Description, Distribution, Activity and Phylogenetic Relationship of Ribosome-Inactivating Proteins in Plants, Fungi and Bacteria," Mini Reviews in Medicinal Chemistry, Vol. 4, No. 5, 2004, pp. 461-476. http://dx.doi.org/10.2174/1389557043403891

[12] T. B. Ng, J. H. Wong and H. Wang, "Recent Progress in Research on Ribosome Inactivating Proteins," Current Protein and Peptide Science, Vol. 11, No. 1, 2010, pp. 37-53. http://dx.doi.org/10.2174/138920310790274662

[13] W. J. Peumans and E. J. Van Damme, "Lectins as Plant Defence Proteins,” Plant Physiology, Vol. 109, No. 2, 1995, pp. 347-352. http://dx.doi.org/10.1104/pp.109.2.347

[14] T. Girbés, C. de Torre, R. Iglesias, J. M. Ferreras and E. Méndez, “RIP for Viruses,” Nature, Vol. 379, 1996, pp. 777-778. http://dx.doi.org/10.1038/379777b0

[15] G. Corrado, P. Delli Bovi, R. Ciliento, L. Gaudio, A. Di Maro, S. Aceto, M. Lorito and R. Rao, "Inducible Expression of a Phytolacca heterotepala Ribosome-Inactivating Protein Leads to Enhanced Resistance against Major Fungal Pathogens in Tobacco,” Phytopathology, Vol. 95, No. 2, 2005, pp. 206-215.

http://dx.doi.org/10.1094/PHYTO-95-0206

[16] L. Polito, M. Bortolotti, D. Mercatelli, M. G. Battelli and A. Bolognesi, "Saporin-S6: A Useful Tool in Cancer Therapy,” Toxins (Basel), Vol. 5, No. 10, 2013, pp. 16981722. http://dx.doi.org/10.3390/toxins5101698

[17] S. V. Govindan and D. M. Goldenberg, "Designing Immunoconjugates for Cancer Therapy," Expert Opinion on Biological Therapy, Vol. 12, No. 7, 2012, pp. 873-890. http://dx.doi.org/10.1517/14712598.2012.685153

[18] J. M. Ferreras, L. Citores, R. Iglesias, P. Jiménez and T. Girbés, "Use of Ribosome-inactivating Proteins from Sambucus for the Construction of Immunotoxins and Conjugates for Cancer Therapy,” Toxins (Basel), Vol. 3, No. 5, 2011, pp. 420-441. http://dx.doi.org/10.3390/toxins3050420

[19] J. M. Ferreras, L. Citores, R. Iglesias, P. Jiménez, A. M. Souza, M. Gayoso and T. Girbés, "Occurrence and New Procedure of Preparation of Nigrin, an Antirribosomal Lectin Present in Elderberry Bark," Food Research International, Vol. 44, No. 9, 2011, pp. 2798-2805. http://dx.doi.org/10.1016/j.foodres.2011.06.004

[20] P. Jiménez, J. Tejero, P. Cabrero, D. Cordoba-Diaz and T. Girbes, "Differential Sensitivity of D-Galactose Binding Lectins from Fruits of Dwarf Elder (Sambucus ebulus L.) to a Simulated Gastric Fluid,” Food Chemistry, Vol. 136, No. 2, 2013, pp. 794-902. http://dx.doi.org/10.1016/j.foodchem.2012.09.011

[21] M. G. Battelli, L. Citores, L. Buonamici, J. M. Ferreras, F. M. de Benito, F. Stirpe and T. Girbés, "Toxicity and Cytotoxicity of Nigrin b, a Two-Chain Ribosome-Inactivating Protein from Sambucus nigra: a Comparison with Ricin,” Archives of Toxicology, Vol. 71, No. 6, 1997, pp. 360-364. http://dx.doi.org/10.1007/s002040050399
[22] M. J. Gayoso, R. Muñoz, Y. Arias, R. Villar, M. A. Rojo, P. Jiménez, J. M. Ferreras, I. Aránguez and T. Girbés, "Specific Dose-Dependent Damage of Lieberkühn Crypts Promoted by Large Doses of Type 2 Ribosome-Inactivating Protein Nigrin b Intravenous Injection to Mice," Toxicology and Applied Pharmacology, Vol. 207, No. 2, 2005, pp. 138-146.

http://dx.doi.org/10.1016/j.taap.2004.12.011

[23] P. Jiménez, D. Cordoba-Diaz, P. Cabrero, M. Aracil, M. J. Gayoso, M. Garrosa, M. Cordoba-Diaz and T. Girbés, "Plasma Accumulation of Vitamin B6 from an Oral Dose in a New Gut In-jury-Regeneration Reversible Mouse Model," Food and Nutrition Sciences, Vol. 4, 2013, pp. 908-917. http://dx.doi.org/10.4236/fns.2013.49118

[24] O. Fumiko, K. Takashi, O. Takahide and F. Yukihiko, "Composition for Strengthening Acid Resistant of Teeth," US Patent No. 5470565, 1995.

[25] T. Girbés, L. Citores, J. M. Ferreras, M. A. Rojo, R. Iglesias, R. Muñoz, F. J. Arias, M. Calonge, J. R. García and E. Méndez, "Isolation and Partial Characterization of Nigrin b, a Non-Toxic Novel Type 2 Ribosome-Inactivating Protein from the Bark of Sambucus nigra L," Plant Molecular Biology, Vol. 22, No. 6, 1993, pp. 1181-1186. http://dx.doi.org/10.1007/BF00028990

[26] A. Ui, S. Kuriyama, M. Kakizaki, T. Sone, N. Nakaya, K. Ohmori-Matsuda, A. Hozawa, Y. Nishino and I. Tsuji, "Green Tea Consumption and the Risk of Liver Cancer in Japan: The Ohsaki Cohort Study,” Cancer Causes and Control, Vol. 20, No. 10, 2009, pp. 1939-1945. http://dx.doi.org/10.1007/s10552-009-9388-x

[27] J. Frank, T. W. George, J. K. Lodge, A. M. RodriguezMateos, J. P. E. Spencer, A. M. Minihane and G. Rimbach, "Daily Consumption of an Aqueous Green Tea Extract Supplement Does Not Impair Liver Function or Alter Cardiovascular Disease Risk Biomarkers in Healthy Men,” The Journal of Nutrition, Vol. 139, No. 1, 2009, pp. 58-62. http://dx.doi.org/10.3945/jn.108.096412

[28] F. Danesi, M. Di Nunzio, E. Boschetti and A. Bordoni, "Green Tea Extract Selectively Acti-vates Peroxisome Proliferator-Activated Receptor Beta/Delta in Cultured Cardiomyocytes,” British Journal of Nutrition, Vol. 101, No. 12, 2009, pp. 1736-1739. http://dx.doi.org/10.1017/S0007114508145871

[29] M. Schmidt, H. J. Schmitz, A. Baumgart, D. Guédon, M. I. Netsch, M. H. Kreuter, C. B. Schmidlin and D. Schrenk, "Toxicity of Green Tea Extracts and Their Constituents in Rat Hepatocytes in Primary Culture," Food and Chemical Toxicology, Vol. 43, No. 2, 2005, pp. 307-314. http://dx.doi.org/10.1016/j.fct.2004.11.001

[30] A. Javaid and H. L. Bonkovsky, "Hepatotoxicity Due to Extracts of Chinese Green Tea (Camellia sinensis): a Growing Concern,” Journal of Hepatology, Vol. 45, No. 2, 2006, pp. 334-335. http://dx.doi.org/10.1016/j.jhep.2006.05.005

[31] X. Jin, R. H. Zheng and Y. M. Li, "Green Tea Consumption and Liver Disease: A Systematic Review,” Liver International, Vol. 28, No. 7, 2008, pp. 990-996. http://dx.doi.org/10.1111/j.1478-3231.2008.01776.x

[32] C. Bunchorntavakul and K. R. Reddy, "Review Article: Herbal and Dietary Supplement Hepatotoxicity,” Alimen- 
tary Pharmacology \& Therapeutics, Vol. 37, No. 1, 2013, pp. 3-17. http://dx.doi.org/10.1111/apt.12109

[33] G. Mazzanti, F. Menniti-Ippolito, P. A. Moro, F. Cassetti, R. Raschetti, C. Santuccio and S. Mastrangelo, "Hepato- toxicity from Green Tea: A Review of the Literature and Two Unpublished Cases,” European Journal of Clinical Pharmacology, Vol. 65, No. 4, 2009, pp. 331-341. http://dx.doi.org/10.1007/s00228-008-0610-7 